\title{
Implementasi Green Supply Chain Management Pada Kelompok Usaha Mikro
}

\author{
Ellysa Nursanti ${ }^{1}{ }^{1 *}$, Sibut $^{2}$, Fuad Achmadi ${ }^{3}$ \\ ${ }^{1,3}$ Program Studi Teknik Industri, Program Pascasarjana, Institut Teknologi Nasional (ITN) Malang \\ ${ }^{2}$ Program Studi Teknik Mesin, Fakultas Teknologi Industri, Institut Teknologi Nasional (ITN) Malang \\ * ellysa.nursanti@lecturer.itn.ac.id
}

\begin{abstract}
Abstrak
Seiring dengan semakin ketatnya persaingan produk, Kelompok Usaha Pengrajin Kerudung Sulam dan Bordir di Malang, Bhakti Collection, harus dapat meningkatkan kualitas produk dan melakukan evaluasi efisiensi sehingga produk memiliki kualitas dan harga yang mampu bersaing di pasar. Di dalam kegiatan produksinya, UKM Bhakti Collection ini melibatkan banyak pihak-pihak lain, diantaranya yaitu stakeholder internal maupun eksternal. Selama ini kegiatan usaha di UKM ini tidak pernah melakukan komunikasi koordinasi terintegrasi (supply chain) dengan para stakeholdernya, walaupun secara proses bisnis terlibat. Dengan adanya tuntutan konsumen untuk dapat menyediakan barang kerudung sulam bordir dengan kualitas yang bagus, update model, harga bersaing, banyak pilihan, mudah didapatkan, cepat secara time to market, maka hal ini memaksa pihak UKM untuk dapat merancang mendesain sistem tata kelola komunikasi koordinasi rantai pasok (supply chain) antar setiap pihak stakeholder yang terlibat sehingga UKM ini dapat meningkatkan performa usahanya, baik dari segi produktivitas, efektifitas dan efisiensi. Supply Chain Management yang diterapkan harus dapat berwawasan lingkungan, menurunkan pemakaian sumber daya, energi dan mengurangi waste, sehingga dapat diwujudkan green supply chain management yang pada akhirnya diharapkan dapat memberikan peningkatan keuntungan yang berkelanjutan bagi unit usaha tersebut.
\end{abstract}

Kata Kunci : Green Supply Chain Management, Produktivitas, Efektivitas, Efisiensi.

\section{Pendahuluan}

Artikel jurnal ini merupakan laporan kegiatan Pengabdian Kepada Masyarakat yang dituliskan dalam bentuk Jurnal Ilmiah.Kegiatan ini ditujukan untuk Kelompok Usaha Mikro, Pengrajin Kerudung Sulam Bordir Bhakti Collection.UMKM Bhakti Collection berdiri sejak awal tahun 2008, beralamatkan di Jl. Terusan Bendungan Wonogiri 21 Malang.Usaha ini dimulai dengan mengaplikasikan sulaman tangan pada berbagai jenis kerudung.Produk yang dihasilkan mendapat respon yang baik dan diminati oleh banyak pelanggannya.Usaha ini semakin berkembang dari waktu ke waktu. Produk yang dihasilkan, telah dijual ke banyak kota: Batam, Jakarta, Bandung, Surabaya, Denpasar, Balikpapan, Bontang, Makasar dan Lombok. Beberapa label fashion nasional ternama juga telah mempercayakan Bhakti Collection untuk menjadi rekanan, diantaranya: Shafira Lamara Persada Group (Shafira, Zoya, Zatta), Alisha Fancy Shop, Mirzani dan Preview Fahira.

Saat ini Bhakti Collection telah memiliki 60 karyawan lepas yang terdiri dari penyulam, pengrajut, pembordir, tukang gambar, tukang potong, tukang jahit, tukang payet dan aplikasi, serta asisten umum. Produk yang dihasilkan juga telah bertambah, tidak hanya kerudung, namun juga ada busana dan mukena.Di dalam kegiatan produksi kerudung sulam, UMKM ini dibantu oleh kelompok pengrajin sulam Maju Bersama yang beralamatkan di Jl. Maluku 11 Pasuruan.UMKM Bhakti Collection menyediakan bahan kerudung yang telah dijahit dan digambar pola sulam, lengkap dengan benang sulamnya, untuk disulam oleh para pengrajin.Selanjutnya kerudung yang telah disulam, dikirimkan kembali ke Bhakti Collection untuk ditambahkan permata, payet dan aplikasi lainnya. 
Seiring dengan semakin ketatnya persaingan produk [1], Bhakti Collection harus dapat meningkatkan kualitas produk dan melakukan evaluasi efisiensi sehingga produk memiliki kualitas dan harga yang mampu bersaing di pasar [2][3][4][5]. Di dalam kegiatan produksinya, UKM Bhakti Collection ini melibatkan banyak pihak-pihak lain, diantaranya yaitu stakeholder internal maupun eksternal.Stakeholder internal ada pihak pemilik modal, pihak manajemen pengelola, pihak pengrajin, pihak karyawan (tukang potong, tukang jahit, tukang gambar, penyulam, tukang pasang payet, tukang pasang permata dan petugas pencuci pengemas) [6].Sementara dari pihak stakeholder eksternal, ada supplier kain kerudung, supplier benang, supplier peralatan, supplier permata swarowski dan asesori, ekspedisi, retailer, konsumen, juga termasuk beberapa rekanan usaha sejenis.

Selama ini kegiatan usaha di UKM ini belum melakukan komunikasi koordinasi terintegrasi (supply chain) dengan para stakeholdernya, walaupun secara proses bisnis terlibat [7]. Dengan adanya tuntutan konsumen untuk dapat menyediakan barang kerudung sulam bordir dengan kualitas yang bagus, update model, harga bersaing, banyak pilihan, mudah didapatkan, cepat secara time to market, maka hal ini memaksa pihak UKM untuk dapat merancang mendesain sistem tata kelola komunikasi koordinasi rantai pasok (supply chain) antar setiap pihak stakeholder yang terlibat sehingga UKM ini dapat meningkatkan performa usahanya, baik dari segi produktivitas, efektifitas dan efisiensi [8][9][10][11]. Supply Chain Management yang diterapkan harus dapat berwawasan lingkungan, menurunkan pemakaian sumber daya, energy dan mengurangi waste, sehingga dapat diwujudkan green supply chain management [12][13] yang pada akhirnya diharapkan dapat memberikan peningkatan keuntungan yang berkelanjutan bagi unit usaha tersebut.

Dari uraian masalah tersebut maka rumusan masalah yang timbul adalah bagaimana merancang green supply chain management yang dapat mendukung kinerja unit usaha Kerajinan Kerudung Sulam dan Bordir di Malang dalam meningkatkan produktivitas, efektifitas dan efisiensinya? Dengan demikian, tujuan dari kegiatan ini adalah merancang, mensosialisasikan, melatih dan menerapkan green supply chain management yang dapat mendukung kinerja unit usaha Kerajinan Kerudung Sulam dan Bordir di Malang dalam meningkatkan produktivitas, efektifitas dan efisiensinya

\section{Metode Kegiatan}

Kegiatan ini dilakukan dalam beberapa tahapan seperti yang terlihat pada Gambar 1 berikut.Mulai dari pengumpulan data business prosess, stakeholder internal dan stakeholder eksternal. Peran posisi masing-masing dan kondisi transaksi antar stakeholder untuk selanjutnya diberikan usulan strategi Green Supply Chain Management yang sesuai, berorientasi pada ramah lingkungan, efisiensi waktu, biaya, tenaga kerja dan energi, efektivitas dan produktivitas kerja [14][15][16].

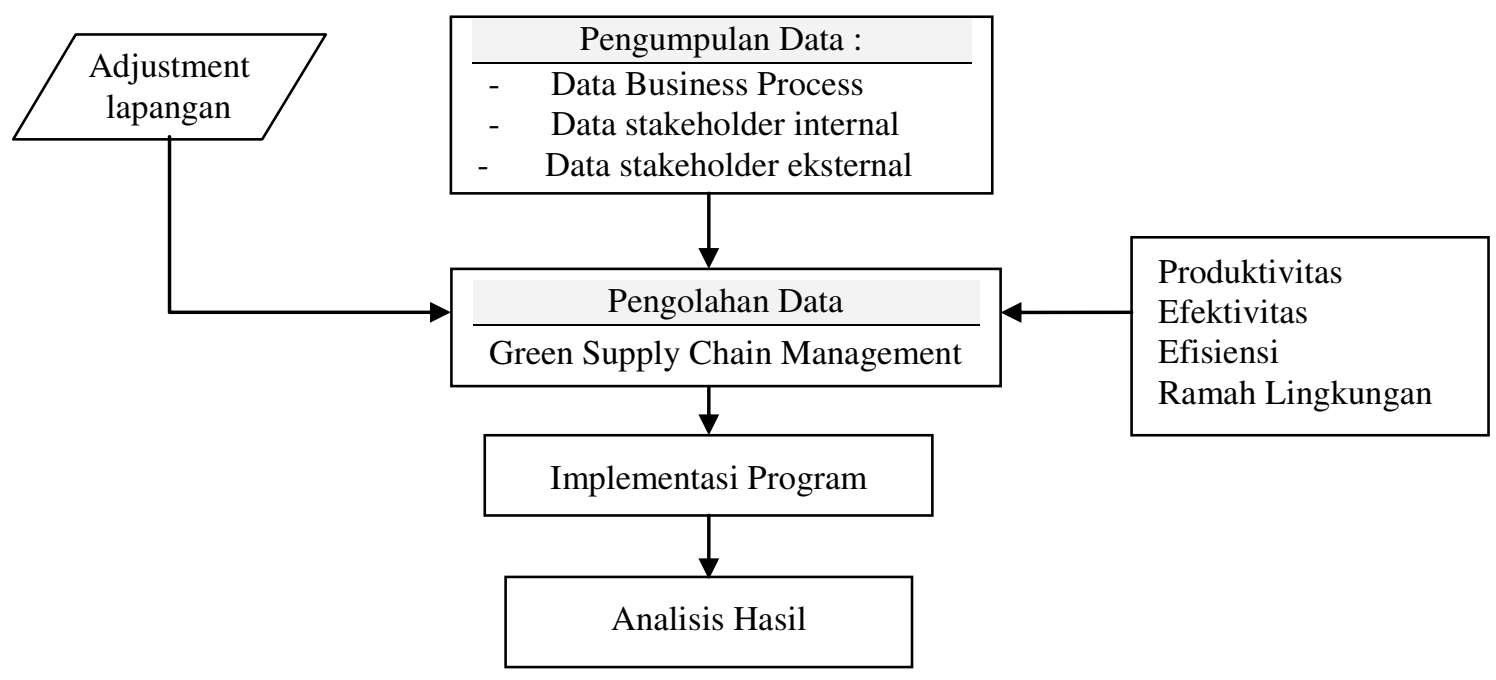

Gambar 1. Alur Kegiatan 
Proses Bisnis Kelompok Usaha Bhakti Collection,meliputi beberapa tahapan sebagai berikut:

\section{Penerimaan Pesanan}

Penerimaan pesanan dilakukan oleh divisi marketing di UD.Bhakti Collection.Pada kondisi saat ini dalam melakukan penerimaan pesanan masih dilakukan secara manual yaitu menggunakan media telepon dan bertemu langsung dalam mengkomunikasikan informasi pesanan. Selain itu dalam pencatatan pesanan juga masih dilakukan secara manual yaitu pencatatan yang berupa paper based, dimana pesanan konsumen direkap dalam buku pesanan yang tersedia. Pesanan akan dicatat sesuai tanggal, nama konsumen, jenis produk, rancangan model, dan jumlah produk yang dipesan.

\section{Persiapan produksi}

Persiapan produksi dilakukan oleh salah satu bagian dari divisi produksi yang berlokasi di Malang.Pada tahap ini dilakukan aktivitas pembuatan desain model kerudung yang menyesuaikan permintaan konsumen seperti ditunjukkan pada Gambar 2.Aktivitas ini dilakukan apabila konsumen memilih untuk membuat rancangan model tersendiri, yang berbeda dengan model yang telah tersedia.Pembuatan desain model diikuti dengan penetuan jenis dan aksesoris yang sesuai dengan rancangan model yang telah dibuat.Kondisi saat ini pada aktivitas persiapan produksi masih dilakukan dengan pertemuan langsung antara karyawan.

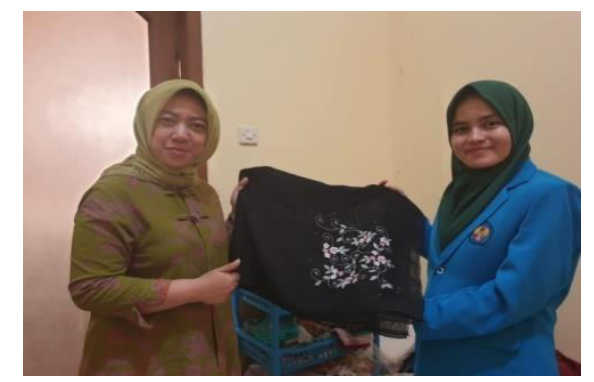

Gambar 2. Pembuatan Design Model Kedurung

\section{Penyimpanan}

Penyimpanan merupakan salah satu divisi bagian purchase pada UD.Bhakti Collection yang berlokasi di Malang. Pada tahap ini dilakukan proses pemeriksaan stok bahan baku, rekap jumlah stok yang keluar masuk, penyimpanan bahan baku, pengiriman bahan baku, serta pengiriman produk. Yang disimpan, mulai bahan baku kain kerudung, benang, permata swarowski dan asesori pelengkap lainnya, barang setengah jadi (work in process) hasil sulam bordir yang menunggu pemasangan asesori, produk akhir jadi yang siap kirim. Berikut pada Gambar 3 ditunjukkan contoh penyimpanan benang dan asesori permata swarowski yang harganya relatif mahal dengan wujud kecil.Pada kondisi penyimpanan saat ini di UD.Bhakti Collection memiliki kekurangan yaitu sering terjadi kesulitan dalam pelacakan informasi stok barang dan lokasi penyimpanannya. Informasi pelacakan informasi stok bahan baku sulit dilacak karena dalam merekap data masih dilakukan secara manual paper based dengan tempat penyimpanan terbuka tersebar, belum terlokalisasi dengan baik.
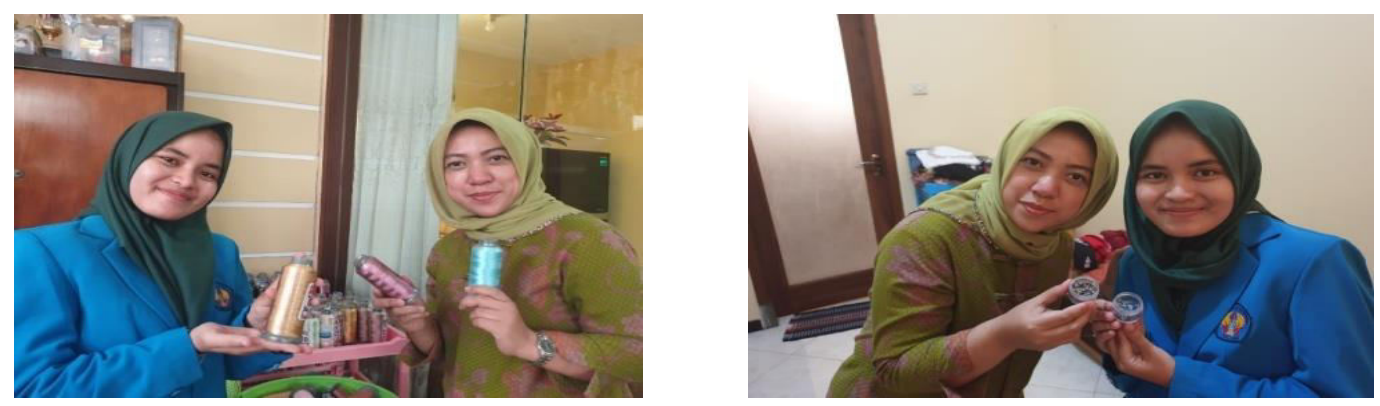

Gambar 3. Penyimpanan Bahan Pembuatan Kerudung 


\section{Pengadaan}

Pengadaan merupakan salah satu divisi bagian purchasepada UD.Bhakti Collection yang berlokasi di Malang. Pada tahap ini dilakukan proses pemesanan bahan baku dan aksesoris apabila stok tidak mencukupi dalam memenuhi permintaan pesanan, selain itu pada divisi pengadaan juga dilakukan uji kualitas pada saat penerimaan bahan baku dan aksesoris, yang dikuti dengan perekapan stok yang masuk. Pada bagian pengadaan untuk menghubungi supplier dalam melakukan pemesanan memerlukan pencarian data supplier terlebih dahulu pada buku pencatatan supplier.Sehingga apabila buku tersebut hilang, maka data supplier tidak dapat dilacak dan memerlukan pencarian informasi ulang. Buku pencatatan supplier hanya memuat informasi seperti namasupplier, alamat supplier, no telepon, jenis barang yang di pasok.

\section{Produksi}

Produksi merupakan salah satu bagian divisi production di UD.Bhakti Collection yang berlokasi di Pasuruan. Aktivitas produksi diawali dengan penerimaan bahan baku yang dikirim dari Malang, kemudian dilanjutkan dengan penugasan ke pengrajin sesuai dengan jenis kerudung yaitu sulam atau bordir. Pada saat penugasan ke pengrajin, sebelumnya perwakilan produksi telah mendatangi UD.Bhakti Collection yang berlokasi di Malang untuk melakukan pembahasan mengenai pesanan sehingga pada saat penugasan pengrajin, informasi mengenai pemesanan dari konsumen sudah dipahami.Setelah pengrajin sudah memahami isi pesanan, pesanan dapat mulai diproduksi. Hasil dari proses pengerjaan dikirim ke Malang untuk dilanjutkan proses finishing. Pemilik dalam mengawasi status pengerjaan produksi masih menggunakan cara manual yaitu dengan media telepon. Sehingga apabila konsumen menanyakan status pesanan, pemilik harus menghubungi pihak produksi di Pasuruan melalui telpon terlebih dahulu.Hal tersebut menyusahkan pemilik, dikarenakan jenis produk yang dihasilkan bervariasi, sehingga terkadang terjadi kesalahan penangkapan informasi terhadap pesanan yang ditanyakan.Hal tersebut disebabkan tidak adanya informasi pengerjaan pesanan yang dihasilkan bagian produksi setiap harinya.

\section{Finishing}

Finishing adalah salah satu bagian dari divisi production di UD. Bhakti Collection yang berlokasi di Malang.Aktivitas pada finishingdiawali dengan melakukan uji kualitas pada hasil produk yang dikiriman dari divisi produksi di Pasuruan.Uji kualitas dilakukkan untuk memastikan hasil produksi yang dihasilkan berkualitas baik.Produk yang lolos dari uji kualitas, kemudian dilanjutkan dengan pemasangan aksesoris, pencucian kerudung, dan setrika.Selanjutnya produk yang telah jadi dilakukan uji kualitas kembali untuk memastikan kembali hasil pemasangan aksesoris dan produk yang dihasilkan telah menunjukkan hasil yang berkualitas baik dan memenuhi permintaan konsumen.Setelah produk sudah selesai dan menunjukkan kualitas baik, maka pesanan dapat dilakukan packaging.Kondisi saat ini pada proses di finishing tidak ada data historis yang tersimpan.

\section{Pengiriman}

Pengiriman produk dilakukan oleh pihak gudang, yang kemudian penyampaian informasi pesanan sudah selesai dan siap dikirim disampaikan oleh karyawan dari bagian marketing.Penyampaian informasi pengiriman produk disampaikan dengan cara manual yaitu dengan media telpon. Saat ini juga pada proses pengiriman tidak ada informasi tanggal pengiriman yang tercatat, sehingga besar kemungkinan kurangnya pengawasan pada pesanan. Hal tersebut mengakibatkan keterlambatan pesanan yang datang.

\section{Alur Proses Produksi}

Pengadaan bahan dan aksesori $\rightarrow$ Kontrol kualitas bahan $\rightarrow$ Proses design $\rightarrow$ Proses prototyping gambar design warna, pemilihan warna dan aksesori $\rightarrow$ Pembuatan sampel $\rightarrow$ Penugasan pekerjaan kepada kelompok pengrajin (Pasuruan, Bangil, Tumpang) $\rightarrow$ Proses produksi (Sulam / bordir) oleh pengrajin $\rightarrow$ Kontrol kualitas hasil sulam $\rightarrow$ Pemasangan Aksesoris $\rightarrow$ Kontrol kualitas pemasangan aksesoris $\rightarrow$ Proses Pencucian $\rightarrow$ Kontrol kualitas Terakhir $\rightarrow$ Ironing dan Packaging $\rightarrow$ Labeling $\rightarrow$ Pengiriman 


\section{Pelaksanaan Kegiatan}

Pelatihan Green Supply Chain dilakukan pada hari Minggu, 8 Desember 2019, bertempat di UKM Bhakti Collection, Jl. Terusan Bendungan Wonogiri 21 Malang. Acara berlangsung dari pukul 09.00 sampai dengan 12.00, dihadiri oleh 27 orang anggota kelompok usaha, mulai dari Pimpinan, karyawan tetap, ketua kelompok pengrajin Sulam Bordir, Tukang Potong, Tukang Gambar, Tukang Pasang Aplikasi sampai staf bagian pencucian, pengemasan dan pengiriman (Gambar 4).

Tujuan sasaran kegiatan ini adalah untuk memberikan wawasan, pengertian dan pemahaman perlunya penerapan Green Supply Chain pada setiap bagian elemen stakeholder internal Kelompok Usaha Bhakti Collection, juga untuk memberikan wawasan kepada pimpinan usaha untuk melaksanakan strategi Green Supply Chain terhadap semua stakeholder eksternalnya. Setiap yang hadir dapat memahami bahwa dirinya dan setiap bagian, merupakan satu kesatuan besar mata rantai pasok kerudung sulam bordir Bhakti Collection, sehingga setiap bagian perlu bersinergi kolaborasi memberikan yang terbaik untuk keuntungan bersama.
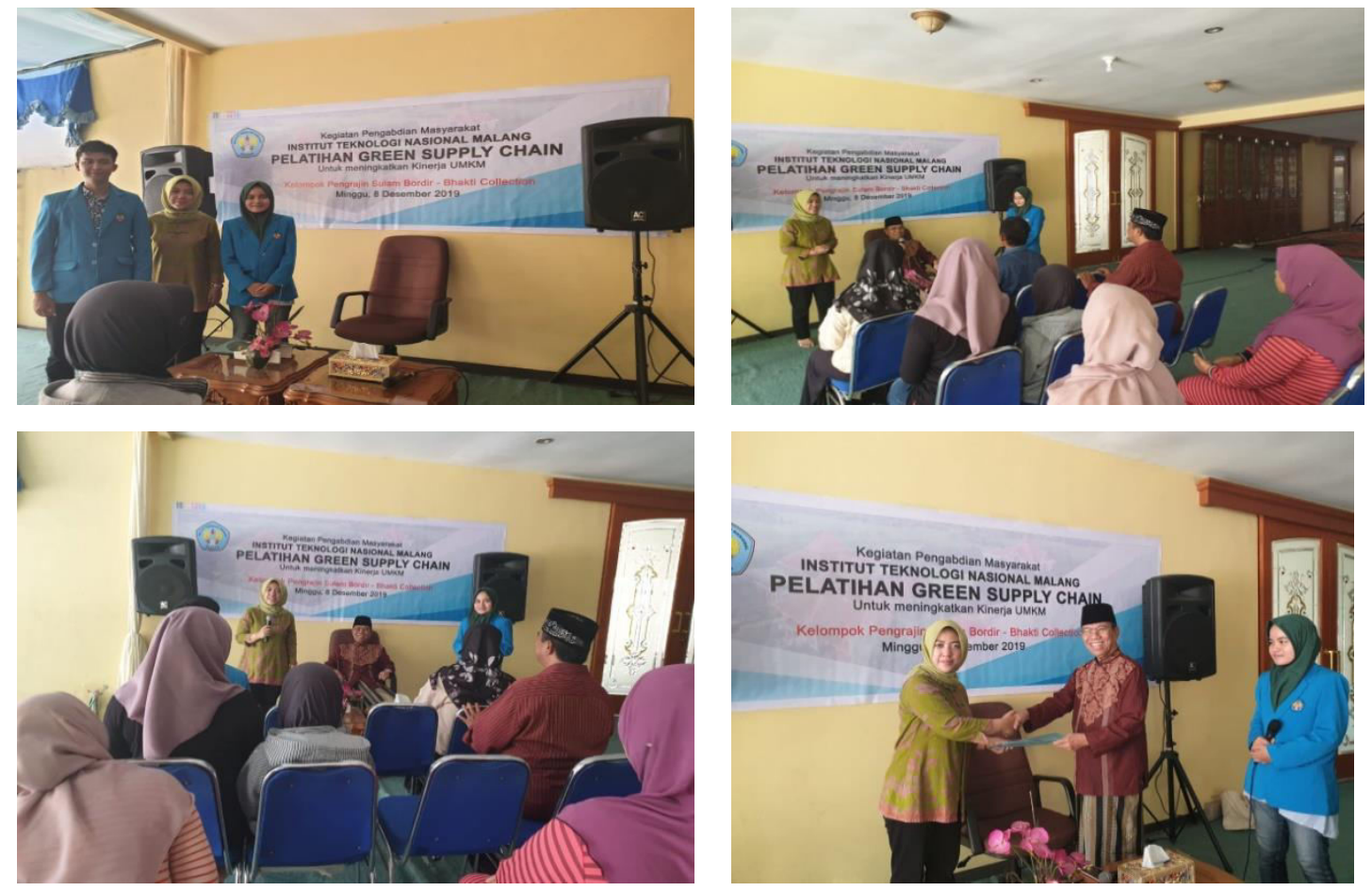

Gambar 4. Kegiatan Pelatihan Green Supply Chain Management

\section{Strategi Green Supply Chain Management yang diusulkan}

\section{Procurement / Pemesanan}

Melakukan kontrak (Business to Business) kepada supplier.dalam proses pembuatan produk. Pada supplier kain melakukan kontrak pada metode pembayaran. Dengan cara memberikan allowance atau kelonggaran dalam membayar. Pada supplier benang melakukan kontrak dengan cara memperbolehkan retur atau pengembalian barang

\section{Produksi}

Melakukan control pada produk defect dengan cara memberikan kode pembuatan sehingga dapat mempercepat proses retur barang ke pengrajin. Pembuatan produk yang berupa handmade (buatan tangan), sehingga dapat menerapkan zero emission. Membuat sistem manajemen permintaan dan inventori berbasis internet terkomputerisasi sehingga dapat meningkatkan efektivitas stock opnameterhadap barang dan inventory control bahan maupun peralatan penunjang lainnya serta 
mengelola permintaan. Melakukan Quality Control langung di pembuat sulam sehingga dapat meminimalkan retur dan menciptakan green reverse logistic. Menerapkan sistem keamanan terintegrasi dan manajemen warehousing sehingga dapat meminimalkan barang hilang.

\section{Distribution / Distribusi}

Melakukan kontrak (Business to Business) dengan jasa pengiriman, terutama pengiriman area Jawa. Diskon untuk setiap pengiriman pada bus Pahala Kencana yaitu sebesar 15\%. Diskon untuk setiap pengiriman pada ekspedisi via kereta api, Hira yaitu sebesar 10\% dari biaya pengiriman. Melakukan pengiriman dalam bentuk batch sehingga dapat menciptakan green transportation.

\section{Implementasi dan Kendala}

Dalam pelaksanaannya, implementasi Green Supply Chain Management menghadapi beberapa tantangan kendala di lapangan, baik untuk stakeholder internal maupun stakeholder eksternal [17][18]. Untuk stakeholder internal, kendalanya pada pemahaman, pengertian dan budaya kerja personal dari masing-masing bagian yang umumnya masih bersifat individu.Para pengrajin umumnya adalah ibu-ibu rumah tangga dari daerah pelosok dengan pendidikan terakhir SD, SMP, Pondok setara pendidikan dasar. Bagi pengrajin seperti ini, tidak difahami bahwa dirinya perlu bekerja dengan standard yang baik sesuai prosedur sehingga dapat mempercepat proses dengan standard kualitas yang ditentukan. Para pengrajin belum memahami pentingnya bersinergi kolaborasi dalam suatu rantai pasok kerudung sulam bordir sehingga dapat memberikan profit bagi seluruh mata rantainya. Sementara itu untuk stakeholder eksternal, kendalanya adalah pada kepercayaan (trust) untuk berkomitmen memberikan layanan prima. Kekhawatiran pimpinan kelompok usaha ini juga beralasan, mengingat beberapa kali terjadi kehilangan barang pada saat pengiriman, pesanan bahan datang tidak dengan kualitas prima, juga konsumen dalam hal ini distributor dan retailer mencoba untuk menjiplak desain dan memproduksinya sendiri dengan kualitas rendah serta memasarkannya, sehingga sangat merugikan kelompok usaha Bhakti Collection.

\section{Kesimpulan}

Berdasarkan uraian yang telah disampaikan pada bab sebelumnya, maka diperoleh kesimpulan Strategi Green Supply Chain yang diusulkan perlu didampingi dengan sosialisasi budaya mutu, sehingga semua elemen stakeholder baik internal maupun eksternal, dapat memahami perannya masingmasing dalam kesatuan mata rantai pasok kerudung sulam bordir Bhakti Collection. Melalui implementasi strategi Green Supply Chain yang diusulkan, Kelompok Usaha pengrajin sulam diharapkan mampu memilah meniadakan aktivitas berulang untuk menghemat waktu dan biaya, juga memastikan semua proses terstandarisasi dari awal sehingga mengurangi peluang reverse logistics. Peluang kerjasama dengan supplier dan rekanan ekspedisi dimungkinkan untuk dapat meningkatkan efisiensi dan efektivitas.Secara umum, strategi Green Supply Chain yang diusulkan diproyeksikan mampu meningkatkan produktivitas, Efektivitas dan Efisiensi Kelompok Usaha tersebut.

\section{Daftar Referensi}

[1] Varchaver, Nicholas. 2004. "Scanning the Globe". Fortune.

[2] Nursanti, E., Handoko, F., Vitasari, P. 2017. Penerapan Manajemen Berbasis Database Dengan MS Access Untuk Meningkatkan Keunggulan Bersaing Pada Usaha Mikro.Jurnal Teknologi dan Manajemen Industri.Pascasarjana.Institut Teknologi Nasional Malang.Vol 3.No. 1.h. 1-4.

[3] Nursanti, E., Sibut, Achmadi, F., Hapsari, D.P.A. 2018. Penerapan Sistem Informasi Terintegrasi Untuk Meningkatkan Kinerja UKM Pengrajin Sulam.Jurnal Teknologi dan Manajemen Industri.Pascasarjana.Institut Teknologi Nasional Malang.Vol 4.No. 2.h. 18-23.

[4] Anderson, Kelly. 2011. "NFB, ARTE France launch 'Bar Code'". Reelscreen. 
[5] Nelson, Benjamin. 1997. From Punched Cards To Bar Codes.

[6] Nursanti, E., Handoko, F. 2016. Pemanfaatan Barcode Scanning Untuk Peningkatan Kualitas dan Inventory.Prosiding Seminar Nasional SENIATI.Institut Teknologi Nasional Malang. h. 58-62.

[7] Gumboh J., Gichira R. 2015. Supply Chain Collaboration among SMEs in Kenya: A Review of Collaboration Barriers. International Journal of Humanities and Social Science.Vol. 5.No. 9. Pp. 223-229.

[8] Omoruyi O., Mafini C. 2016. Supply Chain Management And Customer Satisfaction In Small To Medium Enterprises. Studia Ubb Oeconomica. Vol. 6.No. 3. Pp. 43-58.

[9] Singh K. Rajesh. 2012. Supply Chain Management in SMEs: a case study. Int. J. Manufacturing Research.Vol. 7.No. 2. Pp. 165-180.

[10] Thakkar J. 2008. Supply Chain Management in SMEs: Development of Constructs And Propositions. Asia Pacific Journal of Marketing and Logistics.Vol. 20.No. 1. Pp. 97-131.

[11] Thakkar J., Kanda A., Deshmukh S.G. 2009. Supply Chain Performance Measurement Framework for Small And Medium Scale Enterprises: Benchmarking. An International Journal.Vol. 16.No. 5. Pp. 702-723.

[12] Asrul M. Mustapha. 2013. Sustainable Green Management System (SGMS). Proceedings of the 6th International Conference on Process Systems Engineering, Kuala Lumpur, Malaysia.

[13] Hijaz S., Al - Hujran O. 2015. Green Supply Chain Management and SMEs: a qualitative study. Int. J. Business Information Systems.Vol. 18.No. 2. Pp. 198-220.

[14] Puryono A. Daniel, Kurniawan Y. Samuel. 2017. Penerapan Model Green Supply Chain Management Untuk Meningkatkan Daya Saing UMKM Batik Bakaran.Journal Speed - Sentra Penelitian Engineering dan Edukasi.Vol. 7.No. 3.h. 18-25.

[15] Rao H. Purba. 2019. Green Supply Chain Management: A Study Based on SMEs in India. Journal of Supply Chain Management Systems.Vol. 8. No.1. Pp. 15-24.

[16] Singgih Moses L. 2011. Green Productivity Konsep dan Aplikasi. Teknik Industri - Institut Teknoologi Sepuluh Nopember, Surabaya.

[17] Susanty A., Santosa H., Tania F. 2017. Penilaian Implementasi Green Supply Chain Management di UKM Batik Pekalongan dengan Pendekatan Green SCOR.Jurnal Ilmiah Teknik Industri. Vol. 16.No. 1.h. 55-63.

[18] Wooi C. Goh, Zailani S. 2010. Green Supply Chain Initiatives: Investigation on The Barriers in the Context of SMEs in Malaysia. International Business Management.Vol. 4. No.1. Pp. 20-27. 